\title{
Zorbalıkla Başa Çıkma Stratejileri ve Cinsiyetin Sosyal Beceri Üzerindeki Etkisinin İncelenmesi
}

\author{
The Investigation of the Effect on Social Skills of Gender and Coping \\ Strategies for Bullying
}

DOI: http://dx.doi.org/10.17556/jef.25574

\section{Adem PEKER* Mücahit GÜLTEKİN**}

\section{Özet}

Bu çalışmanın amacı, ortaokul öğrencilerinin zorbalıkla başa çıkma stratejileri ve cinsiyetin sosyal beceri üzerindeki etkisini incelemektir. Araştırma betimsel bir çalışmadır. Araştırmanın katılımcıları 6. 7. ve 8. sınıf düzeylerinden toplam 403 öğrenciden oluşmaktadır. Araştırmada Zorbalıkla Başa Çıkma Stratejileri Öıçeği ve Sosyal Beceri Ölçeği kullanılmıştır. Verilerin çözümlenmesinde çoklu regresyon analizinden yararlanılmıştır. Araştırmada, öğrencilerin sosyal beceri düzeylerini sosyal desteğe başvurma ve iyimserlik stratejilerinin yordadığı görülmüştür. Araştırma sonucunda çaresizlik ve boyun eğme, yardım arama, kaçınma, direnme-karşı koyma stratejileri ve cinsiyetin sosyal beceriyi yordamadığ belirlenmiştir. Araştırma sonuçları literatür doğrultusunda tartışılmıştır.

Anahtar Sözcük: zorbalıkla başa çıkma stratejileri, sosyal beceri

\begin{abstract}
The purpose of this study is to investigate the effect of gender and coping strategies for bullying on social skills in secondary school students. The research is a survey study. The participants of the study are a total of 403 students from 6th, 7th and 8th classes. Coping Strategies for Bullying Scale and Social Skills Scale were used. The multiple regression were used for data analysis. The multiple regression analysis showed that social skills was predicted by seeking social support and optimisim. However, the results of multiple regression analysis indicated that social skills was not predicted by gender, helplessnes and submission, seeking help, avoidance, and resistance strategies. Results were discussed in the light of literature.
\end{abstract}

Keywords: coping strategies for bullying, social skills.

*Yrd. Doç. Dr, Atatürk Üniversitesi, Eğitim Fakültesi, Rehberlik ve Psikolojik Danışmanlık ABD, adem.peker@atauni.edu.tr

**Yrd. Doç. Dr. Afyon Kocatepe Üniversitesi, Eğitim Fakültesi, Rehberlik ve Psikolojik Danışmanlık ABD, mgultekin1@hotmail.com 


\section{Giriş}

Okul döneminde öğrencilerin birbirleriyle olan iletişimi onların psiko-sosyal gelişimi ve sosyalleşmesi açısından son derece önemlidir. Bunun yanında okul öğrencilerin birbirleriyle yoğun bir şekilde iletişim kurmalarını sağlayan önemli bir ortamdır. Ancak bu iletişim zaman zaman olumsuz ilişkileri de içerebilmekte ve bazı öğrencilerin zayıf ve güçsüz gördükleri öğrencilere karşı onların istemediği davranışlarda bulunmasına yol açabilmektedir. Öğrencilerin bu olumsuz davranışı akran zorbalığı olarak adlandırılmaktadır. Akran zorbalığı, öğrencilerin öğrenim hayatları boyunca çok sık yaşadıkları önemli iletişim sorunlarından birisidir. Akran zorbalığı, öğrencilerin okul dönemindeki akademik, duygusal ve sosyal gelişimlerini olumsuz bir biçimde etkileyebilmektedir.

Zorbalıkla ilgili ilk çalışmaları yapan Olweus (1993) akran zorbalığını; bir öğrenciye, bir kişi ya da bir grup tarafından uygulanan sistematik ve sürekli saldırgan davranışlar olarak tanımlamaktadır. Zorbalığa maruz kalan mağdur genellikle kendini koruyamamaktadır. Çünkü Olweus’a (1995) göre zorba ve mağdur arasında bir “güç dengesizliği" vardır. Zorba mağdura göre daha güçlüdür ya da kendini daha güçlü görmektedir. Bu yönüyle zorbalık eşit güçlere sahip iki kişinin kavga yapmasından ayrılmaktadır. Ayrıca bir davranışın zorbalık olarak ifade edilebilmesi için süreklilik özelliği taşımasını gerektiği de vurgulanmaktadır (Nansel ve diğerleri, 2001).

Literatürde farklı zorbalık sınıflandırılmaları yapılmıştır. Yıld1rım (2012) zorbalık üzerine yapılan çalışmalardan bir derleme yaparak zorbalık türlerini, fiziksel (vurma, itme, kesici ve ateşli araçlarla saldırma gibi), sözel (alay etme, lakap takma, küfür etme gibi), sosyal dışlama (yalnızlığa mahkum etme, oyuna almama, görmezden gelme, yok sayma gibi), dedikodu (iftira atma, arkadaşlarını mağdura karşı kışkırtma, mağdur hakkında söylenti çıkarma gibi), eşyalara zarar verme (mağdurun eşyalarını zorla alma, kantinden zorla bir şey 1smarlatma, defter ya da kitaplarını karalama gibi) şeklinde sınıflamıştır.

Türkiye'de zorbalık davranışın görülme sıklığına ilişkin yap1lan araştırmalar, bu davranışın giderek yaygınlaşan bir problem olduğunu göstermektedir. Çınkır ve Karaman-Kepenekçi’nin (2003) yaptıkları araştırmada liselerde öğrencilerin sözel (\%44), fiziksel (\%30), duygusal (\%18) ve cinsel zorbalığa (\%9) maruz kaldıkları görülmek- 
tedir. Atik ve Kemer’in (2008) ilköğretim öğrencileri üzerinde yaptıkları çalışmada öğrencilerin \%32'sinin zorbalık olayından etkilendikleri ifade edilmektedir. Pişkin'in (2010) ortaokul öğrencileri arasında yaptığı araştırmada öğrencilerin \%35'inin mağdur, \%30'nun zorba, \%6'sının de hem zorba hem de mağdur olduğu bulgulanmıştır. Kartal ve Bilgin'in (2012) ilköğretim öğrencileri üzerinde yaptıkları araştırmada erkek öğrencilerin 1/3'ünün zorbalığa maruz kaldığ1, 1/3'ünün de zorbalık yaptığı bildirilmiştir.

Ada (2010), ortaokul öğrencilerine yaptığı çalışmada öğrencilerin disiplin durumlarına göre, zorbalık yapmanın ceza alanlarda ceza almayanlara göre anlamlı düzeyde yüksek olduğunu bulmuştur. Araştırmanın diğer bir bulgusunda yaş ve kardeş sayısının akran zorbalığ yapma puanlarını anlamlı düzeyde yordadığı tespit edilmiştir. Ayas ve Pişkin (2011) "sözel mağduriyet" hariç diğer tüm alt ölçeklerde erkeklerin kızlardan daha fazla zorbalığa uğradıklarını ve "dışlama" hariç diğer tüm alt ölçeklerde kızlardan daha fazla zorbalık yaptıklarını ortaya koymaktadır. Bulgular ayrıca, mağdur puanı en yüksek grubun Endüstri Meslek Lisesi; zorbalık puanı en yüksek grubun ise Özel Lise öğrencileri olduğunu göstermektedir. Bulgulara göre en az zorbalığa uğrayan ve en az zorbalık yapan grubun ise Anadolu Lisesi öğrencileri olduğu anlaşılmaktadır.

Zorbalıkla ilgili yapılan araştırmalarda erkeklerin kızlara göre hem daha fazla zorbalık yaptıkları hem de daha fazla zorbalığa maruz kaldıkları tespit edilmiştir. (Bilgiç, 2007; Carney ve Merrel, 2001; Craig ve diğerleri, 2009; Demeray ve Malecki, 2003; Dölek, 2002; Eşici, 2007; Pişkin ve Ayas, 2005; Salmivalli ve Nieminen, 2002; Tak1ş, 2007).

Yapılan araştırmalarda zorbalık yaşayanların negatif değerlendirilme korkusu, depresif semptomlar ve sosyal kaçınma (Storch, Nock, Masia-Warner, Barles, 2003); okul korkusu ve konsantrasyon sorunları (Bernstein ve Watson, 1997), düşük benlik saygısı, depresyon, kaygı (Kapcı, 2004), okul yaşamından memnun olmama, okula isteksiz gitme, okulu güvensiz bir yer olarak görme ve okul ortamını mutsuzluk verici bir yer olarak algilama (Rigby, 2004; Olweus, 2005) gibi sorunlar yaşadıkları ortaya konulmuştur. Zorbalığa uğrayan kişilerde okuldan korkma, okuldan kaçma, yırtılmış kitaplar ve çamurlu elbiselerle okuldan gelme, alt ıslatma, tırnak yeme, çekingen davranışlar sergileme, kabuslar görme, özellikle sabahları psiko-somatik rahat- 
sızlıklar gösterme, beklenmedik kesikler ve yanıkların ortaya çıkması, arkadaşları ve ailesi ile sorunlar yaşamaya başlama, öfkeli ve mantık dışı davranışlarda bulunma gibi belirtileri görüldüğü bildirilmiştir (European Community European Social Fund, 2001, akt. Koç, 2006),

Literatürde mağdurların daha çok fiziksel olarak zayıf, çekingen ve sosyal becerileri iyi olmayan çocuklar arasından seçildiği belirtilmektedir (Koç, 2006). Mağdur öğrencilerin kişilik özelliklerinin aktarıldığ 1 bir çalışmada (European Community European Social Fund, 2001, akt. Koç, 2006) bu öğrencilerin fiziksel olarak zayıf, utangaç, çekingen, içe dönük, başkalarına daha az ilgi gösteren ve iletişim becerileri yetersiz, uyum güçlüğü çeken, sosyal olarak duyarsız, kolay boyun eğen ve sosyal becerileri yeterli olmayan çocuklar olduğu dile getirilmektedir.

Sosyal beceri literatürde, çevreye uyum sağlama, uygun iletişim yollarını kullanarak yaşanan ya da yaşanması muhtemel sözel ya da sözel olmayan çatışmaları ve problemleri çözebilme ve bunlarla başa çıkabilme becerisi olarak tanımlanmaktadır (Matson, Matson ve Rivet, 2007). Diğer bir tanımda sosyal beceri etkin dinleme, atılgan davranışta bulunma, bir ilişkiyi başlatma, sürdürme ve sonlandırma gibi temel iletişim becerileri ölçülmesi olarak belirtilmektedir (Silvera, Martinussen ve Dahl, 2001).

Yapılan araştırmalar sosyal becerilere sahip olmayan çocukların okullarda zorbalığın daha çok mağduru haline geldiklerini göstermektedir. Arkadaş ilişsileri güçlü olan öğrencilerin daha az mağdur konumunda oldukları bulunmuştur (Hilooğlu, 2009; Totan, 2008). Arora (1987) sosyal becerilere sahip olmamanın zorbalığın tanımında önemli bir yer tuttuğunu belirterek, zorbalığın, mağdur öğrencilerin yeterli sosyal becerilere sahip olmadıkları için mağdur konumuna düştüklerini ve zorbaların da bundan faydalanarak saldırganlık araçlarını kullanma yoluyla sosyal baskınlığı ele geçirdiklerini ve sürdürdüklerini ifade etmektedir.

Son dönemlerde okul zorbalığı ile araştırmaların sayısı artmasına rağmen müdahale hizmetleri ve başa çıkma stratejileri ile ilgili çok az sayıda çalışmanın yapıldığı görülmektedir. Bu nedenle bu çalışma, alanyazında var olan bu eksikliği gidermede bir katkı sağlama amacı taşımaktadır. Zorbalığın önlenmesi konusunda müdahale yaklaşımlarının planlanmasında öğrencilerin hangi başa çıkma stratejilerinin kullanıldığının belirlenmesinin zorbalıkla baş etmede yararlı ola- 
cağı düşünülmektedir. Bu bakımdan bu araştırma; "Ortaokul öğrencilerinin zorbalıkla başa çıkma stratejileri ve cinsiyeti sosyal beceri düzeylerini yordamakta mıdır?" sorusuna cevap aramaktadır.

\section{Yöntem}

\section{Araştırmanın Modeli}

$\mathrm{Bu}$ araştırma, tarama modelinde betimsel bir çalışmadır. Tarama modelinde; ilgilenilen olay, grup gibi birim ve duruma ait değişkenler, ayrı ayrı betimlenmeye çalışılır. Diğer bir ifadeyle tarama modeli, geçmişte ya da halen var olan bir durumu var olduğu şekliyle betimlemeye amaçlayan bir araştırma yaklaşımıdır (Karasar, 2006).

\section{Çalışma Grubu}

Araştırma, 2013-2014 öğretim yılında Bursa ve Erzurum ilinde 6., 7. ve 8. sinıflara devam eden 403 öğrenci ile gerçekleştirilmiştir. Bu araştırmada seçkisiz olmayan örnekleme yöntemlerinden uygun örnekleme yöntemi kullanılmıştır. Bu yöntem araştırmacıya zaman ve ulaşılabilirlik açısından kolaylık sağlamaktadır. Ayrıca bu yöntemde örnekleme alınacak birimler seçkisizlik ilkesine bağlı olmaksızın belirlenir (Bayram, 2009). Araştırma da zaman, para ve işgücü kaybının önlenmesi amacıyla daha kolay ulaşabilenecek okullar seçkisizlik ilkesine bağlı olmadan belirlenerek bu okullardaki öğrenciler örnekleme alınmıştır. Araştırmaya katılan öğrencilerin $198(\% 49,13)$ tanesi kız, $205(\% 50,87)$ tanesi ise erkektir. Ortaokulda öğrenim gören öğrencilerin \%30’u 6. sinıfta, \%34'ü 7.sınıfta ve \%36'sı da 8.sınıfta öğrenim görmektedirler.

\section{Veri Toplama Araçlart}

\section{Kișisel Bilgi Formu}

Öğrencilerin nitelikleri hakkında bilgi toplamak için araştırmacılar tarafından geliştirilmiştir. Kişisel bilgi formu; cinsiyet, algılanan akademik başarı ve devam edilen sınıf ile ilgili sorular içermektedir.

\section{Zorbalıkla Başa Çıkma Stratejileri Ölçeği}

Bu ölçek ortaokul ve lise düzeyinde öğrenim görmekte olan öğrencilerin zorbalığa maruz kalmaları durumunda kullandıkları başa 
çıkma stratejilerini belirlemek üzere Seçer (2013) tarafından geliştirilmiş öz bildirime dayalı Likert tipi bir ölçme aracıdır. Ölçek toplam 27 madde ve çaresizlik ve boyun eğme (ÇBE), yardım arama (YA), sosyal desteğe başvurma (SDB), kaçınma (K), direnme-karşı koyma (DKK) ve iyimserlik (I) alt boyutlarından oluşmaktadır.

Açımlayıcı faktör analizi sonucunda toplam varyansın \%55,19'unu açıklayan bir yapı elde edilmiştir. Elde edilen altı faktörlü bu yapının doğrulayıcı faktör analizi ile model uyumu test edilmiştir. Doğrulayıcı faktör analizi sonuçları elde edilen faktör yapısına ilişkin model uyum indekslerinin iyi düzeyde olduğunu göstermiştir. Uyum indeksi değerleri ise RMSEA $=.056$, RMR $=.044$, NFI $=.91$, NNFI $=$ .92 , CFI=.92, IFI=.92, RFI=.94, AGFI=.90, GFI=.92 olarak bulunmuştur.

Ölçeğin güvenirlik analizleri için iç tutarlık, iki yarı ve test tekrar test güvenirliğine bakılmıştır. ZBÇSÖ’nin iç tutarlık güvenirlik katsayısı ölçek toplamı için .84, ve alt boyutlar için sırayla .83, .81, .85, .84, .85, .82 olarak saptanmıştır. ZBÇSÖ’nin iki yarı güvenirlik katsayısı ölçek toplamı için .83 ve alt boyutlar için sırayla .82, .80, .82, .82, .84, .83 olarak tespit edilmiştir. ZBÇSÖ’nin test tekrar test güvenirlik katsayısı ölçek toplamı için .86 alt boyutlar için sırayla $.84, .82, .83,81, .83, .84$ olarak bulunmuştur.

Benzer ölçek geçerliği için ZBÇSÖ’nin akademik stres, benlik saygısı ve stresle başa çıkma tarzları ölçekleri ile ilişkisine bakılmıştır. Elde edilen sonuçlarda ZBÇSÖ’nün alt boyutları ile diğer ölçeklerin -.23 ile .85 arasında bir ilişkinin olduğu bulgulanmıştır.

ZBÇSÖ'den her bir alt boyut için ayrı ayrı toplam puan elde edilebilmektedir. Alt boyutlar için elde edilen toplam puan artışı zorbalıkla başa çıkma stratejilerinin kullanımını göstermektedir. Elde edilen sonuçlar doğrultusunda zorbalıkla başa çıkma stratejileri ölçeğinin ortaokul ve lise öğrencileri üzerinde tarama amaçlı araştırmalarda kullanılabilecek geçerli ve güvenilir bir ölçme aracı olduğu söylenebilir.

\section{Sosyal Beceri Ölçeği}

Sosyal Beceri Ölçeği Tromso Sosyal Zeka Ölçeğinin (TSZÖ) alt boyutlarından biridir. TSZÖ Silvera, Martinussen ve Dahl (2001) tarafından geliştirilmiştir. Ölçek, sosyal zeka düzeyini ortaya koymak üzere hazırlanmış 21 maddelik kendini tanımlama türünde bir araçtır. TSZÖ sosyal bilgi süreci, sosyal beceriler ve sosyal farkındalık olmak 
üzere üç ayrı boyuttan oluşmaktadır. Ölçekteki maddeler için yedili Likert tipi bir cevaplama anahtarı hazırlanmıştır. Anahtarda en düşük puan 1, en yüksek puan ise 7'dir. Silvera, Martinussen ve Dahl (2001) tarafından yapılan Cronbach alfa iç tutarlık katsayıları sosyal bilgi süreci için .81, sosyal beceri için .86 ve sosyal farkındalık için .79 bulunmuştur.

Ölçeğin Türkçeye uyarlanması ise Doğan ve Çetin (2009) tarafından yapılmıştır. Ölçeğin yapı geçerliğini değerlendirmek amacıyla yapılan açımlayıcı faktör analizi sonucu TSZÖ’nün özgün formunda olduğu gibi üç faktörlü bir yapıya sahip olduğu gözlenmiştir. TSZÖ’nün alt boyutları toplam varyansın \% 44,79'unu açıklamaktadır. Özgün formun Türk örneklemde doğrulanıp doğrulanmayacağını belirlemek üzere yapılan doğrulayıcı faktör analizi (DFA) yapılmıştır. İşlem sonucu elde edilen modelin uyum indeksi değerleri RMSEA $=0.057, \mathrm{NFI}=0.92, \mathrm{CFI}=0.95, \mathrm{IFI}=0.95, \mathrm{RFI}=0.91$, GFI $=0.92$ ve $A G F I=0.91$ olarak bulunmuştur. Bu uyum indeksi değerleri modelin uyumunun yeterli olduğunu ortaya koymaktadır.

TSZÖ’nün ölçüt geçerliğini saptamak Yüksel (1997) tarafindan Türkçeye uyarlanan Sosyal Beceri Envanteri (SBE) kullanılmıştır. Sosyal Beceri Envanteri puanları ile Sosyal Bilgi Süreci alt boyutu arasında .41, Sosyal Beceri alt boyutu arasında .61, Sosyal Farkındalık alt boyutu arasinda ve toplam puanlar arasinda .51 korelasyon katsayısı bulunmuştur.

TSZÖ’nün güvenirliğini belirlemeye yönelik olarak test tekrar test, iç tutarlık ve test yarılama yöntemleri kullanılmıştır. İç tutarlık (Cronbach alpha) güvenirlik kat sayısı ölçeğin tümü için .83 olarak saptanmıştır. Alt ölçeklere ilişkin iç tutarlık güvenirlik katsayıları ise "Sosyal Bilgi Süreci” alt boyutu için .77, "Sosyal Beceriler” alt boyutu için .84 ve "Sosyal Farkındalık" alt boyutu için .67 olarak bulunmuştur.

TSZÖ’nün test yarılama yöntemiyle yapılan güvenirlik çalışmasında ölçeğin tamamı için .75 güvenirlik katsayısı tespit edilmiştir. Alt ölçekler için ise "Sosyal Bilgi Süreci” alt boyutu için .76, "Sosyal Beceriler" alt boyutu için .83, "Sosyal Farkındalık" alt boyutu için .71 güvenirlik katsayısı belirlenmiştir. Test tekrar test güvenirlik katsayısı tüm ölçek için .80 olarak bulunmuştur. Alt ölçeklerde ise "Sosyal Bilgi Süreci” alt ölçeğinde. 68, “Sosyal Beceriler” alt ölçeğinde .81 ve "Sosyal Farkındalık" alt ölçeğinde .95 olarak bulunmuştur. 
TSZÖ’den elde edilen üç faktörlü yapı üç ayrı ölçek olarak değerlendirilmekte ve her alt ölçekten ayrı ayrı toplam puan elde edilmektedir. Ayrıca ölçekten toplam puanda elde edilebilmektedir. Gerek toplam puanda gerekse alt ölçeklerde puan artışı yüksek sosyal zekâyı ifade etmektedir.

\section{Verilerin Analizi}

Araştırmada analizler SPSS 16.0 ile yapılmıştır. Öğrencilerin zorbalıkla başa çıkma stratejilerinin ve cinsiyetin sosyal beceri düzeyini yordayıp yordamadığı çoklu regresyon analizi ile test edilmiştir. $\mathrm{Bu}$ analizlerde sosyal beceri ölçeği test puanları bağımlı değişken, zorbalıkla başa çıkma stratejileri ölçeği alt ölçek puanlarının her biri ile cinsiyet bağımsız değişken, olarak ele alınmıştır. Cinsiyet ile ilgili dummy değişkenin oluşturulmasında kızlar=1, erkekler $=0$ olarak kodlanmiştır.

Analizler yorumlanırken regresyon katsayıları, standartlaştırılmış regresyon katsayıları, regresyon katsayılarına ilişkin t-testi sonuçları, çoklu korelasyon katsayıları ve açıklama katsayıları dikkate alınmıştır. Analizler sürecinde bağımsız değişkenler arasında çoklu bağlantı sorunu olup olmadığını belirlemek için değişkenler arasındaki korelasyonlar, varyans şişkinlik değerleri, tolerans değerleri ve koşullu indeks değerleri incelenmiştir. Korelasyonların 0,80 üzerinde olmaması, varyans şişkinlik değerleri 10'dan büyük olmaması, tolerans değerleri ve koşullu indeks değerlerinin 30 değerini geçmemesi istatistiksel olarak beklenmektedir (Büyüköztürk, 2007; Kalayc1, 2006). İncelemeler sonucunda bağımsız değişkenler arasında regresyon analizini engelleyecek düzeyde bir çoklu bağlanım olmadığı anlaşılmıştır

\section{Bulgular}

ZBÇSÖ’nin alt boyutları ÇBE, YA, SDB, K, DKK ve İ alt ölçeklerinden alınan puanlar ile Sosyal Beceri Ölçeği'nden alınan puanlar arasında anlamlı bir ilişkinin olup olmadığını belirlemek için korelasyon analizi yapılmıştır. Sonuçlar Tablo 1'de verilmiştir. 
Tablo 1. Regresyon Analizine Alınan Değişkenlere İlişkin Korelasyon, Ortalama ve Standart Sapma Değerleri

\begin{tabular}{|c|c|c|c|c|c|c|c|}
\hline Değiş̧kenler & 1 & 2 & 3 & 4 & 5 & 6 & 7 \\
\hline 1.Sosyal Beceri & 1 & & & & & & \\
\hline 2.Çaresizlik ve Boyun Eğme & $.02 *$ & 1 & & & & & \\
\hline 3. Yardım Arama & $.08^{*}$ & $.14^{*}$ & 1 & & & & \\
\hline 4. Sosyal Desteğe Başvurma & $.19 *$ & $.18^{*}$ & $.34^{*}$ & 1 & & & \\
\hline 5. Kaçınma & $.023^{*}$ & $-.10^{*}$ & $.03 *$ & $.11^{*}$ & 1 & & \\
\hline 6. Direnme-Karşı Koyma & $.09 *$ & $.17 *$ & $.18^{*}$ & $.43^{*}$ & $-.02 *$ & 1 & \\
\hline 7. İyimserlik & $.12 *$ & $.11 *$ & $.13^{*}$ & $.10^{*}$ & $.11^{*}$ & $-01 *$ & 1 \\
\hline $\bar{X}$ & 26.45 & 3.22 & 4.40 & 7.49 & .57 & 9.34 & 3.45 \\
\hline Ss & 5.51 & 2.03 & 3.41 & 4.22 & .98 & 3.47 & 2.48 \\
\hline
\end{tabular}

Tablo 1 incelendiğinde sosyal beceri ile zorbalıkla başa çıkma stratejileri arasında .02 ile .19 arasında değişen, pozitif ve anlamlı ilişkiler olduğu gözlenmektedir. Ayrıca Zorbalıkla Başa Çıkma Stratejileri Ölçeği'nin alt boyutları arasında pozitif ve negatif yönde farklılık gösteren anlamlı ilişkiler olduğu görülmektedir.

ZBÇSÖ’nün alt boyutları ile cinsiyetin sosyal beceri üzerindeki etkisini incelemek amacıyla kurulan regresyon analizinin sonuçları Tablo 2'de sunulmuştur.

Tablo 2. Zorbalıkla Başa Çıkma Stratejileri Ölçek Puanları ve Cinsiyetin Sosyal Beceri Ölçek Puanlarını Yordama Düzeylerine İlişkin Çoklu Regresyon Analizi Sonuçları

\begin{tabular}{llccccccc} 
Model & Değişsenler & $\mathbf{B}$ & S. H. & $\boldsymbol{\beta}$ & $\mathbf{t}$ & $\mathbf{F}$ & $\mathbf{R}$ & $\mathbf{R}^{2}$ \\
\hline 1. & Sabit & 24.60 & .55 & & 44.71 & & & \\
& SDB & .248 & .064 & .190 & 3.87 & 14.94 & .19 & .036 \\
2. & Sabit & 23.90 & .64 & & 37.51 & & & \\
& SDB & .23 & .064 & .179 & 3.64 & & & .036
\end{tabular}


A.Peker, M.Gültekin / EÜ Ĕ̈itim Fakültesi Dergisi, 16(1) (2014), 139-156

$\begin{array}{llllllll}\text { İyimserlik } & .23 & .109 & .105 & 2.14 & 9.82 & .22 & .047\end{array}$

Sosyal beceriyi yordayan değişkenlere ilişkin çoklu regresyon analizi sonuçlarına göre 1 . modelde sosyal desteğe başvurmanın sosyal becerinin \%3.6'sını açıkladığı, bunun yanında sosyal becerinin açıklanmasına 2. modelde iyimserliğin \%1.1'lik bir katkı sağladığı görülmüştür. Adı geçen iki değişken birlikte sosyal becerinin \%4,7’sini açıklamaktadır. Standardize edilmiş regresyon katsayılarına $(\beta)$ göre değişkenlerin sosyal beceri üzerindeki göreli etkisi; sosyal desteğe başvurma $(\beta=.190, t=-3.87, p=.01)$ ve iyimserlik için $(\beta=.105$, $\mathrm{t}=2.14, \mathrm{p}=.01$ ) şeklindedir.

Çaresizlik ve boyun eğme, yardım arama, kaçınma, direnmekarşı koyma başa çıkma stratejileri ve cinsiyetin yapılan regresyon analizinde sosyal beceri üzerinde yordayıcı bir etkisinin olmadığı belirlenmiştir.

\section{Sonuç ve Tartışma}

$\mathrm{Bu}$ araştırma da zorbalıkla başa çıkma stratejileri ve cinsiyetin sosyal beceri üzerindeki etkisi incelenmiştir. Araştırma sonucunda sosyal beceriyi sosyal desteğe başvurma ve iyimserlik başa çıkma stratejilerinin yordadığı; çaresizlik ve boyun eğme, yardım arama, kaçınma, direnme-karşı koyma başa çıkma stratejileri ile cinsiyetin sosyal beceri üzerinde yordayıcı bir etkisinin olmadığı görülmüsstür.

Bu bulgu Gürsoy'un (2011) lise öğrencilerin ailelerinden ve arkadaşlarından destek algılamaları arttıkça zorbalığa maruz kalmaları azaldığını saptadığı, Tura'nın (2008), ortaokul öğrencilerinin algıladıkları sosyal destek azaldıkça zorbalığa maruz kalmalarının arttığını bulduğu, Totan'ın (2008) güçlü akran ilişkilerine sahip olan ergenlerin mağdur olma olasılıklarının düştüğünü ortaya koyduğu araştırma sonuçlarıyla örtüşmektedir.

Kristensen ve Smith (2003) zorbalıkla baş etmede kendine güven/problem çözme stratejisinin en çok tercih edilen strateji olduğunu ve bunu sırası ile uzak durma, sosyal destek alma, içselleştirme ve dişsallaştırma stratejilerinin izlediğini bulgulaması bu araştırma sonucuyla tutarlılık göstermektedir. Zorbalık ile sosyal destek arasındaki ilişki 
inceleyen başka bir araştırmada, akran desteği olmayan öğrencilerin zorbalığa daha fazla maruz kaldıklarını, zorbalığa karışmayan öğrenciler mağdur ve zorba statüsünde yer alan öğrencilere göre arkadaşlık ilişkilerinin daha olumlu olduğunu algıladıklarını ortaya koymuştur (Bilgiç, 2007; Sipahi, 2008).

Nitekim araştırmacıların algıladıkları sosyal destek düzeyi yüksek olan öğrencilerde zorbalık ve zorbalığa uğrama düzeylerinin daha düşük olduğunu belirtmeleri araştırma bulgusu ile tutarlılık göstermektedir (Baldry, 2004; Davidson ve Demeray, 2007; Holt ve Espelage, 2007; Morris, 2007). Eşkisu'nun (2009) yaptığı araştırma sonuçlarına göre, sosyal desteğin hem zorbaca davranışların önlenmesinde, hem zorbalığa uğradıktan sonra bu durumun daha az zarar görerek atlatılmasında hem de bireyin kendine güven düzeyinin artarak zorbalıktan kaçınmasında ve zorbalığa karşı durabilmesinde önemli bir değişken olduğunu göstermektedir.

Flaspohler ve diğerleri (2009) ilk ve orta dereceli okullarda yaptıkları çalışmada zorbaca davranışta bulunan veya maruz kalan öğrencilerin yaşam memnuniyetlerinin ve arkadaş ve öğretmen desteğinden yararlanma düzeylerinin, zorbalığa karışmayanlara göre daha düşük olduğunu ifade etmiştir.

Cowie ve Wallace (2000) öğrencilerin zorbalığa maruz kaldıklarında "görmezden gelme", "onlara durmalarını söyleme" ve "arkadaşlarından yardım isteme" gibi yöntemleri kullanacaklarını belirtmeleri, kızların ağlama ve yardım isteme davranışlarının erkeklere göre daha fazla görüldüğünü ifade etmeleri bu araştırmanın bulgularıyla örtüşmemektedir. Yine Ünalmış'ın (2010) ortaokul öğrencilerin zorbalığa uğradıklarında, en fazla "karşılık vermeme ve görmezden gelme”, davranışları gösterdiğini tespit ettiği araştırma bulgusu da bu araştırma sonuçlarıyla benzerlik göstermemektedir.

Yöndem ve Totan'ın (2008) farklı zorbalık statülerindeki ergenlerin başetme yaklaşımları araştırma sonuçlarına bakıldığında kendine güvenli, iyimser, çaresiz ve boyun eğici yaklaşımların kullanımında anlamlı farklar gözlenmiştir. Sosyal destek aramada farklı zorbalık statüleri yönünden anlamlı fark görülmemiştir. Bu bulgu bu araştırmanın sonuçlarıyla aynı doğrultuda değildir. Hunter, Boyle ve Warden'in (2004) ilköğretim ve lise öğrencileri üzerinde yürüttüğü çalışmada kızların zorbalığa maruz kaldıklarında erkeklere göre daha 
fazla sosyal destek aradıklarını bulgulaması bu araştırmanın sonuçlarıyla farklılaşmaktadır.

Öğrencilerin zorbalığa maruz kaldıklarında sosyal desteğe başvurma ve iyimserlik başa çıkma stratejilerini kullanmaları, öğrencilerin bu sorunla baş etmede durumu pasif bir şekilde kabullenmediklerini göstermektedir. Ayrıca bu sonuç, sosyal desteğe başvurma ve iyimserlik başa çıkma stratejilerinin sosyal beceriyi artırdığı dolayısıyla da öğrencilerin daha kolaylıkla zorbalıkla baş edebilmesini ve zorbalık gibi olumsuz davranışlara yönelme ihtimalini azalttığı şeklinde yorumlanabilir.

Sosyal beceri düzeyi yüksek bireylerin, diğer insanların ruh hâllerini, isteklerini ve arzularını, sevinçlerini ve kızgınlıklarını, dürtülerini, iniş çıkışlarını anlayabilme ve bunlara göre davranışlarını ayarlayabilme yeteneği; uyumlu sosyal sosyal ilişkiler kurma, başkalarıyla iyi geçinebilme, iyi iletişim kurabilme becerisi (Matson, Matson ve Rivet, 2007; Silvera, Martinussen ve Dahl, 2001) gibi özelliklere sahip olmaları zorbalık durumuyla karşılaştıklarında etkin bir şekilde başa çıkma stratejisini kullanabileceklerini göstermektedir. Diğer bir deyişle zorbalık durumuna maruz kaldıklarında bireylerin sosyal desteğe başvurma ve iyimserlik başa çıkma stratejilerini kullanmalarını bu olumsuz durumdan daha az etkilenmelerini sağlamaktadır.

Okullarda zorbalığın önlenmesi için geliştirilen programlarda; mağdur ve zorbalar için sosyal beceri programlarının geliştirilmesi ve zorbalar ve mağdurlarla düzenli konuşmalar yapılmasının önemi üzerinde durulmuştur. Öğrencilerin kişisel gelişimleri için sosyal becerinin geliştirilmesi önem taşımaktadır. Sosyal beceriler karşımızdaki bireylerle olan iletişim dilimizi belirler. Kişiler arası ilişkilerinde uygun bir iletişim dili geliştiren çocuklar, iletişim dili olarak akranlarına zorbalık yapmayı seçmeyeceklerdir (Heinrichs, 2003).

Nitekim öğrencilerin iletişim becerileri arttıkça zorba ve mağdur olma durumunun azalması (Sönmezay, 2010), öğrencilerin sosyal kontrol becerileri artıkça zorba ya da mağdur olma durumlarının zayıflaması (Ünalmış, 2010), mağdurların sosyal becerilerinin düşük olması (Fox ve Boulton, 2005), zorbalığa karışmayan öğrencilerin olumlu sosyal davranışlarının ve sosyal beceri toplam puanlarının zorbalığa karışan öğrencilere göre daha yüksek olması (Hilooğlu, 2009) zorbalığa uğrayan öğrencilerin sosyal becerilerinin düşük olduğunun göstergesidir. 
Çocuğun zorbalığa uğradıktan sonra bu konu hakkında çevresindekilerden (aile, arkadaş, öğretmen) bu sorunu nasıl çözebileceği ile ilgili olarak destek alması ve sorunu birlikte çözmeye çalışmaları çocuğun zorbalıktan kaçınmasını ve karşı koyabilmesini sağlayabilmektedir. Çünkü zorbalık; kişiye karşılaştığı sorunları aşmada yalnız olmadığını, bu sorunu aşmada her türlü desteğin sağlanacağı mesajını vermekte ve kişinin kendine güvenini artırmakta aynı zamanda zorbalığa uğradığında ise yine yakın çevredekilerin desteği ile bu stres verici durumun üstesinden daha kolay bir şekilde gelebileceğini düşünmektedir (Eşkisu, 2009).

Araştırmadan elde edilen bulgular sosyal desteğe başvurma ve iyimserlik başa çıkma stratejilerinin sosyal beceriyi pozitif bir şekilde etkilediğini göstermektedir. Araştırma sonuçlarına göre bireylerin sosyal desteğe başvurma ve iyimserliğin arttırılmasının sosyal becerilerini arttıracağı söylenebilir. Araştırmadan elde edilen bu bulguların zorbalıkla başa çıkma ilgili önleyici programlar geliştirme noktasında araştırmacılara önemli katkılar sunacağı söylenebilir.

Akran zorbalığı gerek Türkiye'de gerekse diğer ülkelerde son derece yaygın ve önemli bir sorun olarak karşımıza çıkmakta ve çok fazla öğrencinin mutsuz olması, okula devamsızlık yapması, akademik başarısızlık, depresyon, kaygı, sosyal kaçınma gibi çeşitli psikolojik problemler yaşaması gibi sorunları beraberinde getirebilmektedir. Dolayısıyla bu tür olayların önlenebilmesi için bu araştırmadan elde edilen bulguların farklı örneklemlerde ve farklı yordayıcı değişkenler açısından gelecekteki araştırmalarla da desteklenmesi ve zenginleştirilmesinin önemli olacağ düşünülmektedir.

Zorbalığı önlemede ve zorbalık sonucu oluşan risk durumlarını en aza indirmede öğrenci tarafından algılanan sosyal desteğin ve iyimserliğin önemli olmasından dolayı okullarda bu konuyla ilgili çalışma grupları oluşturularak mağdur durumda olan öğrencilere yönelik okul yönetimi, öğretmenler, öğrenciler ve aileler tarafından her türlü destek sağlanması gerekmektedir. 


\section{Kaynaklar}

Ada, Ş. (2010). Analyzing peer bullying of 6., 7., and 8. grades primary school students from the aspect of different variables in Erzurum. Education and Science, 35 (158), 90-100.

Arora, C.M. (1987). Defining bullying for a secondary school. Educational and Child Psychology, 3-4, 110-120.

Atik, G., \& Kemer, G. (2008). İlköğretim ikinci kademe öğrencileri arasındaki zorbalığı yordamada problem çözme becerisi, sürekli öfke-öfke ifade tarzları ve fiziksel özyeterliliğin rolü. Dokuz Eylül Buca Eğitim Fakültesi Dergisi, 23, 198-206.

Ayas, T., \& Pişkin, M. (2011). Lise öğrencileri arasındaki zorbalık olaylarının cinsiyet, sınıf düzeyi ve okul türü bakımından incelenmesi. İlköğretim Online, $10(2), 550-568$.

Baldry, A.C. (2004). The impact of direct and indirect bullying on the mental and physical health of Italian youngsters. Aggressive Behavior, 30, 343-355.

Bayram, N. (2009). Sosyal bilimlerde spps ile veri analizi. Bursa: Özge Kitapevi.

Bilgiç, E. (2007). İlköğretim 1. kademede görülen zorbaca davranışların sinıf değişkenleri ve atmosferi algılamalarına göre algılanması. Yayınlanmamış yüksek lisans tezi, Çukurova Üniversitesi, Adana.

Büyüköztürk, Ş. (2007). Sosyal bilimler için veri analizi el kitabı. İstatistik, araştırma deseni, spss uygulamalart ve yorum. Ankara: Pegem A Yayıncılık.

Carney, J. V., \& Merrell, K. W. (2001). Bullying in schools: Perspectives on understanding and preventing an international problem. School Psychology International, 22, 364-382.

Cowie, H., \& Wallace, P. (2000). Peer support in action: From bystanding to standing. London: Thousand Oaks.

Craig, W., Harel-Fisch, Y., Fogel-Grinvald, H., Dostaler, S., Hetland, J., SimonsMorton, B., et. al. (2009). A cross-national profile of bullying and victimization among adolescents in 40 countries. Internarional Journal of Public Health, 54(2), 216-224.

Çınkır, Ş., \& Karaman-Kepenekçi, Y. (2003). Öğrenciler arası zorbalık. Kuram ve Uygulamada Eğitim Yönetimi, 34, 236-253.

Davidson, L.M., \& Demeray, M.K. (2007). Social support as a moderator between victimization and internalizing-externalizing distress from bullying. School Psychology Review, 36 (3), 383-405.

Demaray, M.K., \& Malecki, C.K. (2003). Perceptions of the frequency and importance of social support by students classified as victims, bullies and bully/victims in an urban middle school. School Psychology Review, 32, 471-490.

Doğan, T., \& Çetin, B. (2009). Tromso sosyal zekâ ölçeği Türkçe formunun faktör yapısı, geçerlik ve güvenirlik çalışması. Kuram ve Uygulamada Ĕgitim Bilimleri, 9(2), 691-720.

Dölek, N. (2002). İlk ve ortaöğretim okullarındaki ögrenciler arasında zorbaca davranışların incelenmesi ve zorbalığ önleme tutumu geliştirilmesi progra- 
mının etkisinin araştırılması. Yayınlanmamış doktora tezi, Marmara Üniversitesi, İstanbul.

Eşici, H. (2007). İlköğretim yedinci sınıf öğrencilerinin temel ihtiyaçlarının karşılanma düzeyi ile zorbaca davranışları arasındaki ilişki. Yayınlanmamış yüksek lisans tezi, Gazi Üniversitesi, Ankara.

Eşkisu, M. (2009). Liseli öğrencilerin zorbalık düzeyleri ile aile işlevleri ve algılanan sosyal destek arasındaki ilişkinin incelenmesi. Yayınlanmamış yüksek lisans tezi, İstanbul Üniversitesi, İstanbul.

Flaspohler, P. D., Elfstrom, J. L., Vanderzee, K. L., Sink, H. E., \& Birchmeier, Z. (2009). Stand by me: The effects of peer and teacher support in mitigating the impact of bullying on quality of life. Psychology in the Schools, 46(7), 636-649.

Fox, C. L., \& Boulton, M. J. (2005). The social skills problems of victims of bullying: Self, peer and teacher perceptions. British Journal of Educational Psychology, 75, 313-328.

Gürsoy, E. C. (2010). Ergenlerde sosyo demografik özellikler ve algllanan sosyal destek ile akran zorbalı̆̆ına maruz kalmanın incelenmesi. Yayınlanmamış yüksek lisans tezi, Maltepe Üniversitesi, İstanbul.

Heinrichs, R. R. (2003). A whole-school approach to bullying: Special consideration for children with exceptionalities. Intervention in School and Clinicinal, 38, 195.

Hilooğlu, S. (2009). Illköğretim ikinci kademe ögrrencilerinin zorbaca davranışlarını yordamada sosyal beceri ve yaşam doyumunun rolü. Yayınlanmamış yüksek lisans tezi, Çukurova Üniversitesi, Sosyal Bilimler Enstitüsü, Adana.

Holt, M.K., \& Espelage, D.L. (2007). Perceived social support among bullies, victims and bully-victims. Journal Youth Adolescence, 36, 984-994.

Hunter, S. C., Boyle, J. M., \& Warden, D. (2004). Help seeking amongst child and adolescent victims of peer -aggression and bullying: The influence of school stage, gender, victimisation, appraisal and emotion. British Journal of Educational Psychology, 74, 375-390.

Kalaycı, Ş. (2006). SPSS uygulamalı çok değişkenli istatistik teknikleri. Ankara: Asil yayın dağıtım Ltd. Şirketi.

Kapcı, G. E. (2004). İlköğretim öğrencilerinin zorbalığa maruz kalma türünün ve sıklığının depresyon, kaygı ve benlik saygısıyla ilişkisi. Ankara Üniversitesi Eğitim Bilimleri Dergisi, 37, 1-13.

Karasar, N. (2006). Bilimsel araştırma yöntemi. Ankara: Nobel Yayın Dağıtım.

Kartal, H., \& Bilgin, A. (2012). İlköğretim öğrencilerinin zorbalığın nedenleri ile ilgili algıları. Gaziantep Üniversitesi Sosyal Bilimler Dergisi, 11(1), 25 48.

Koç, Z. (2006). Lise ögrencilerinin zorbalık düzeylerinin yordanması. Yayınlanmamış doktora Tezi, Gazi Üniversitesi Eğitim Bilimleri Enstitüsü, Ankara.

Kristensen, S.M., \& Smith, P.K. (2003). The use of coping strategies by Danish children classed as bullies, victims, bully/victims, and not involved, in 
response to different (hypothetical) types of bullying. Scandinavian Journal of Psychology, 44, 479-489.

Matson, J.L., Matson, M.L., \& Rivet, T.T. (2007). Social skills treatments with children with autism spectrum disorders. Behavior Modification,31,682707.

Morris, K.L. (2007). Familial antecedents of bullying and victimization: The moderating role of social support. Yayımlanmamış doktora tezi, Universtiy of California Riverside, California.

Nansel, T. R., Overpeck, M., Pilla, R.S., Ruan, W. J., Simons-Morton, B.,\& Peter S.P. (2001). Bullying behaviors among US youth: Prevalence and association with psychosocial adjustment. Jama, 285 (16), 2094-2100.

Naylor, P., \& Cowie, H. (1999). The effecitiveness of peer support systems in challenging school bullying: The perspective and ezperiences of teachers and pupils. Journal of Adolescence, 22, 467-479.

Olweus, D. (1993). Bullying at school: What we know and what We can do? Oxford and Cambridge, MA: Blackwll Publishers.

Olweus, D. (1995). Bullying or peer abuse at school: Facts and intervention. Current Directions in Psychological Science, 4(6), 196-200.

Olweus, D. (2005). Bullying at school. Australia, Oxford: Blackwell.

Pişkin, M. (2002). Okul zorbalığı: Tanımı, türleri ilişkili olduğu faktörler ve alınabilecek önlemler. Kuram ve Uygulamada Ĕ̌itim Bilimleri Dergisi, 2,531 .

Pişkin, M., \& Ayas, T. (2005, Eylül). Lise öğrencileri arasında yaşanan akran zorbalığı olgusunun okul türü bakımından karşılaştırılması. VIII. Ulusal Psikolojik Danışma ve Rehberlik Kongresi, Marmara Üniversitesi Atatürk Eğitim Fakültesi, İstanbul.

Pişkin, M. (2010). Examination of peer bullying among primary and middle school children in Ankara. Eğitim ve Bilim, 35(156), 175-189.

Rigby, K. (2004). Addressing bullying in schools: Theoretical perspectives and their implications. School Psychology International, 25(3), 287-300.

Salmivalli, C., \& Nieminen, E. (2002). Proactive and reactive aggression among school bullies, victims and bully-victims. Aggressive Behavior, 28(1), 30-44.

Seçer, İ. (2013). Zorbalıkla başa çıkma stratejileri ölçeğinin geliştirilmesi: Geçerlik ve güvenirlik çalışması. Ístanbul 2013 Dünya Psikolojik Danışma Rehberlik Kongresi, 465-466.

Silvera, D. H., Martinussen, M., \& Dahl, T. I. (2001). The tromso social intelligence scale, a self-report measure of social intelligence. Scandinavian Journal of Psychology, 42, 313-331.

Sönmezay, H. (2010). Lise öğrencilerinde zorbalı̆̆ın iletişim becerileri ve algılanan sosyal destek ile ilişkisinin incelenmesi. Yayınlanmamış yüksek lisans tezi, Ankara Üniversitesi, Ankara.

Storch, E. A., Nock, M.K., Masia-Warner, C., \& Barlas, M.E. (2003). Peer victimization and social-psychological adjustment in hispanic and 
A.Peker, M.Gültekin / EÜ Ĕ̈itim Fakültesi Dergisi, 16(1) (2014), 139-156

African-American children. Journal of Child and Family Studies, 12(4), 439-452.

Takış, Ö. (2007). Orta ögrretim kurumları için geliştirilen zorbaca davranışlarla baş edebilme programının etkisinin incelenmesi. Yayınlanmamış yüksek lisans tezi, Ankara Üniversitesi, Ankara.

Totan, T. (2008). Ergenlerde zorbalı̆̆ın anne, baba ve akran ilişkileri açısından incelenmesi. Yayınlanmamış yüksek lisans tezi, Abant İzzet Baysal Üniversitesi, Sosyal Bilimler Enstitüsü, Bolu.

Tura, G. (2008). Akran zorbalı̆̆ına maruz kalmayı yordayan özellikler. Yayınlanmamış yüksek lisans tezi, Hacettepe Üniversitesi, Ankara.

Ünalmış, A. (2010). İlköğretim 6, 7 ve 8. sınıf öğrencileri arasında yaşanan zorbalığı farklı değişkenler açısından incelenmesi. Yayınlanmamış yüksek lisans tezi, Gaziosmanpaşa Üniversitesi, Tokat.

Yıldırım, R. (2012). Akran zorbalığı. Celal Bayar Üniversitesi Sosyal Bilimler Dergisi, 10(2), 39-51.

Yöndem, Z. D., \& Totan, T. (2008). Ergenlerde zorbalık ve başetme. Çukurova Üniversitesi Eğitim Fakültesi Dergisi, 8(2), 53-68.

\section{Extended Summary}

Purpose

The peer interaction of the child is one of the important factors that affect the socialization of the children during the school periods. However, this interaction includes some negative relationships as well and the child may fall within a pattern called bullying (Olweus, 1995). Bullying is defined as a student being exposed repetitively to negative behaviors of one or more other students (Olweus, 1994). Researches on prevalence of bullying (Demaray and Melecki, 2003; Fox \& Boulton, 2005; Holt and Espelage, 2007; Morris, 2007; Olweus, 1993, 1995; Selekman and Vessey, 2004) have indicated that bullying is common, Studies in Turkey (Ayas and Pişkin, 2011; Gürsoy, 2010; Eşkisu, 2009; Hilooğlu, 2009; Koç, 2006; Pişkin, 2010; Totan, 2008; Ünalmış, 2010) have displayed that bullying is common.

Peer bullying is an important impediment for the safety of schools and students' social security. It is important to see a continuum in the negative behavior in order to consider a behavior as bullying. Bullying in the school environment must have specified division of roles agreed upon by participants. It is impossible being a bully or doing bullying alone in the community, because bullying occurs in a communal environment, and it is maintained with the participation of other individuals.

School bullying is a factor that affects school climate and students' development in a negative way. Therefore, there is a need to shed light on the various aspects of individualistic and social characteristics of this phenomenon in order to carry out some prevention or intervention work in an effective way. The purpose of this study is to investigate the effect of gender and strategies to cope with bullying on social skills. 


\section{Method}

The participants of the study are a total of 403 adolescents from 6th, 7th and 8th classes. Of the students \%49,13 $(\mathrm{n}=198)$ are girl and \%50,87 $(\mathrm{n}=205)$ are male. The research has been designed with a survey model. The students were administered "Strategies to Cope with Bullying Scale " which was developed by the Seçer (2013), "Social Skills Scale" which was adapted to Turkish by Doğan and Çetin (2009) and "Personal Information Form" which was developed by the researcher is define demographical and family of studensts. The multiple regression were used for data analysis. The statistical analyses of the study have been carried out using SPSS 16 pack-age software.

\section{Result and Discussion}

The multiple regression analysis showed that social skills was predicted by social support approach and optimisim. However, the results of multiple regression analysis indicated that social skills was not predicted by gender, helplessnes and submission, seeking help, avoidance, and resistance strategies.

This finding is similar to finding of Gürsoy (2011)'s, Turan (2008)'s and Totan (2008)'s study. In Bilgiç (2007) and Sipahi (2008)'s study, it was found that students who do not receive peer support were more exposed to bullying. Indeed, researches indicated that students with high levels of perceived social support are less likely to be bully and victim (Baldry, 2004; Davidson and Demeray, 2007; Holt and Espelage, 2007; Morris, 2007).

Hunter, Boyle and Warden (2004) found that girls seek social support when exposed to bullying more often than boys do. This finding is different of Cowie and Wallace (2000)'s, Ünalmış (2010)'s, Yöndem and Totan (2008)'s, Kristensen and Smith (2003)'s studies.

\section{Conclusion}

More comprehensive studies analyzing the peer bullying from the aspect of different variables might be conducted. Considering social support approach and optimisim a significant predicter of the social skills, consciousness-raising studies should be applied interested people and personnel in order to understand the students. School administrators and teachers should consider such differences in their bullying prevention programs in order to reduce bullying incidents in their schools. Based on this results school counselors plan preventive guidance and counseling programs in their school. 